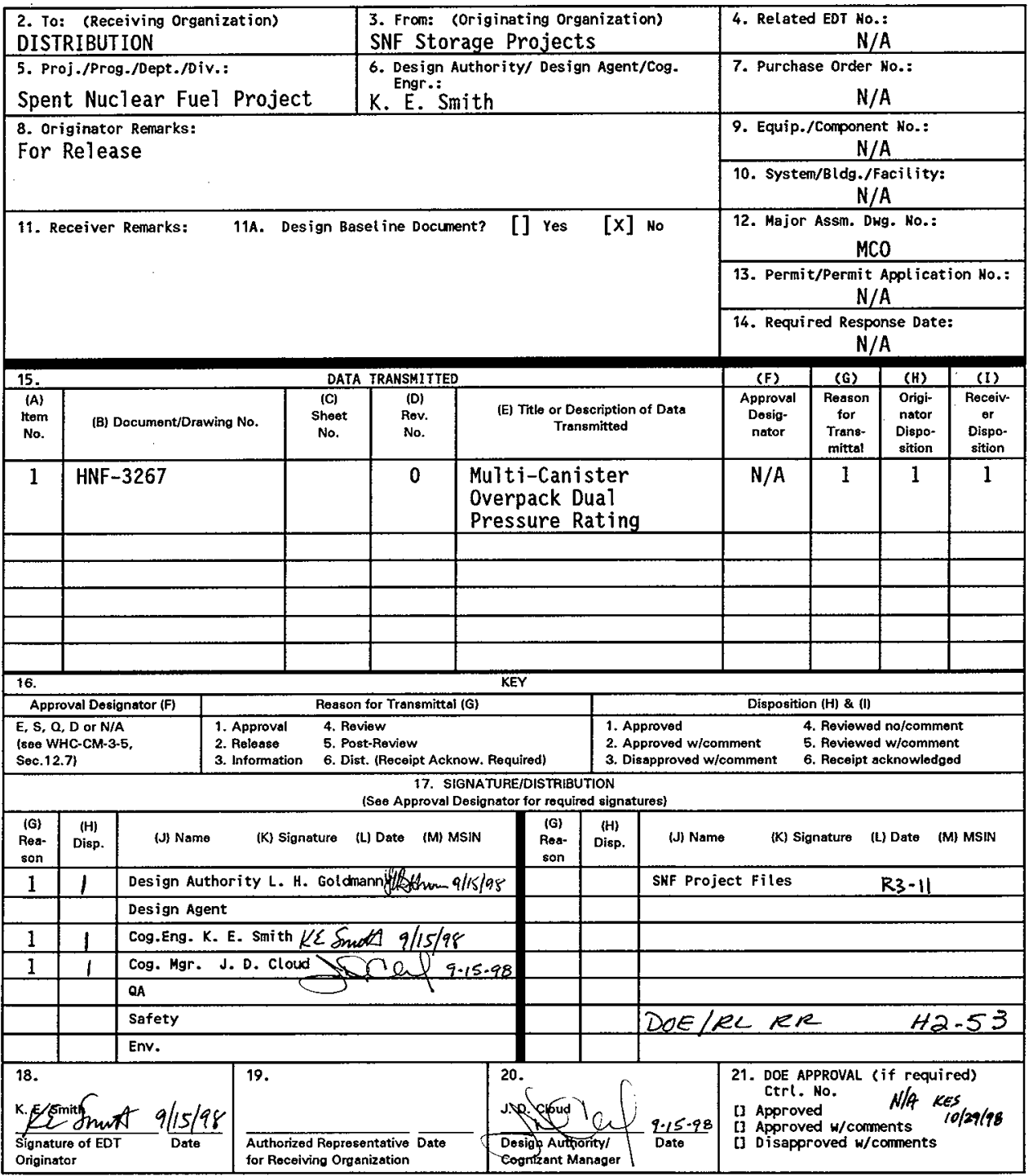

BD-7400-172-2 (05/96) GEF097 


\title{
Multi-Canister Overpack Dual Pressure Rating
}

\author{
K. E. Smith
}

DE\&S Hanford, Inc., Richland, WA 99352

U.S. Department of Energy Contract DE-AC06-96RL13200

$\begin{array}{lll}\text { EDT/ECN: } & 625079 & \text { UC: } 600 \\ \text { Org Code: } & 2 T 340 & \text { Charge Code: LE004 } \\ \text { B\&R Code: } & \text { EW7040000 } & \text { Total Pages: } 4\end{array}$

Key Words: MCO, Spent Fuel, Design Pressure, Packaging, Container, Issue, XM-19, Collar

Abstract: The SNF Project will change the Multi-Canister Overpack (MCO) design pressure rating in the mechanical closure configuration to 150 psig to permit substitution of $304 \mathrm{~L} / 304$ stainless steel for the higher cost XM-19 in the MCO collar. The 450 psig pressure rating for the final welded MCO will remain unchanged.

TRADEMARK DISCLAIMER. Reference herein to any specific comsercial product, process, or service by trade name, trademark, manufacturer, or otherwise, does not necessarily constitute or imply its endorsement, recommendation, or favoring by the United states Government or any agency thereof or its contractors or subcontractors.

Printed in the United States of America. To obtain copies of this document, contact: Document Control Services, P.O. Box 950, Mailstop H6-08, Richland WA 99352, Phone (509) 372-2420; Fax (509) 376-4989.

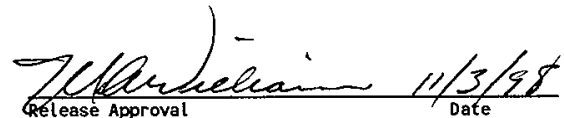

Release Approval

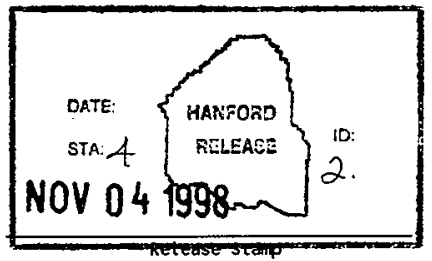




\section{Issue Closure Package}

\section{Issue: $\quad$ MCO Dual Pressure Rating}

Lead:

K. E. Smith

\section{KE Smitt $9 / 15 / 98$}

MCO Implementation

Manager, DE\&S Hanford

\section{Approvals:}

Chief Engineer:

A. M. Segrest

DE\&S Hanford

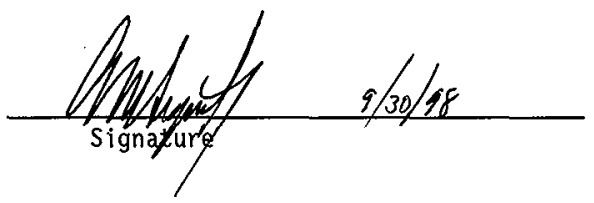

Technical Operations:

J. A. Swenson

Manager

DE\&S Hanford

Construction Projects:

A. R. Hollins

Manager

DE\&S Hanford

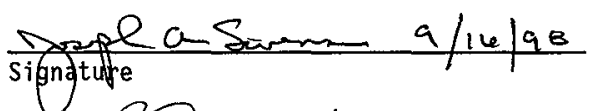

Nuclear Safety:

Robert G. Morgan

Manager

DE\&S Hanford
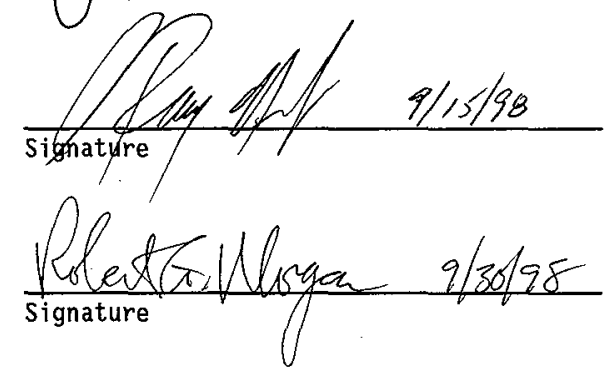

MCO Design Authority:

L. H. Goldmann

DE\&S Hanford

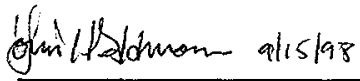
Signature 
HNF-3267, Rev.0

MULTI-CANISTER OVERPACK

DUAL PRESSURE RATING

\section{Introduction}

Revision 4 of the MCO Performance Specification, Reference 1, raised the design pressure of the MCO to 450 PSIG. This increase in design pressure from 150 PSIG was driven by RL's assessment that there was a need to improve margin and reduce risks associated with assumptions supporting the bounding pressure calculation for the MCO Sealing Strategy. The increase in design pressure required design changes to be made to the closure system (higher strength collar material) and to the bottom cap (thickness increase) of the MCO. After the design changes were initiated, requests were made to evaluate a lower design pressure for the shield plug closure system. A lower design pressure would not require the higher strength collar material, resulting in material cost savings.

\section{Discussion}

RL's technical advisory group (TAG) requested a review, Reference 2, of the design, with the intent of demonstrating that the derating of the shield plug closure system to 150 PSIG from the revision 4 design pressure of 450 PSIG would permit use of $304 \mathrm{~L}$ collar material, a less costly material than the XM19 collar material requiried for the 450 PSIG pressure rating.

The issue was discussed with the design agent, and a review was formally requested in Reference 3 . Reference 3 requested an evaluation of the potential for derating the mechanical closure design pressure. The design agent completed the review, Reference 4, and the results conciude that derating is possible by using dual certified $304 \mathrm{~L}$ alloy with 304 yield properties for the MCO collar. The derating allows for a 150 PSIG design for the shield plug closure system and a 450 PSIG design for the MCO with the cover cap welded to the collar.

This derating of the shield plug closure system does pose some difficulties to the ASME Code hydrostatic testing of the MCO main shell assembly, which consists of the collar, 1/2 inch thick shell section, and the bottom cap. The 450 PSIG design test requirement may require a special test seal plug be fabricated to hydrostatically test the collar, shell, and bottom cap as an assembly. The proposed methods for performing MCO pressure testing are discussed in HNF-3270, MCO Pressure Testing.

While the MCO is in the CSB with only a shield plug assembly installed, the MCO design rating would be 150 PSIG. This change to a dual pressure rated MCO will require the SNF project to revisit hazards and accident analyses for potential changes due to the derated (150 PSIG) shield plug installed. While the dual pressure rating concept appears feasible at this time, there may be 
other unforseen impacts which will need to be addressed as they are identified.

A fabrication cost savings of approximately $\$ 3 M$ is realized from changing the collar material from XM-19 to dual certified 304L/304. Cost increases to address pressure testing difficulties, revisit safety analyses, and revise the MCO Design Report are estimated at less than $\$ 200 \mathrm{~K}$.

\section{Conctusion}

With the considerations discussed above, the SNF Project will change the design pressure rating of the shield plug closure system to 150 PSIG, which will permit use of $304 L / 304$ dual certified material for the MCO collar. The 450 PSIG rating for the final welded MCO will remain unchanged.

The three MCOs being fabricated for test and training purposes will be made with 304L/304 dual certified stainless steel collars. Methods for performing pressure testing are addressed in HNF-3270.

\section{References}

1. HNF-S-0426 "Specification for the Spent Nuclear Fuel Multi-Canister Overpack" Revision 4

2. TAG memo, David G Strawson to Charles Loftis, April 21, 1998.

3. Letter, Louis Goldmann to John Tanke, July 6, 1998

4. Letter, Jon Tanke, Parsons to R. Butler, DESH, August 5, 1998 


\section{DISTRIBUTION COVERSHEET}

Subject: MCO ISSUE PAPERS PER ATTACHED DISTRIBUTION INDEX

\section{DISTRIBUTION}

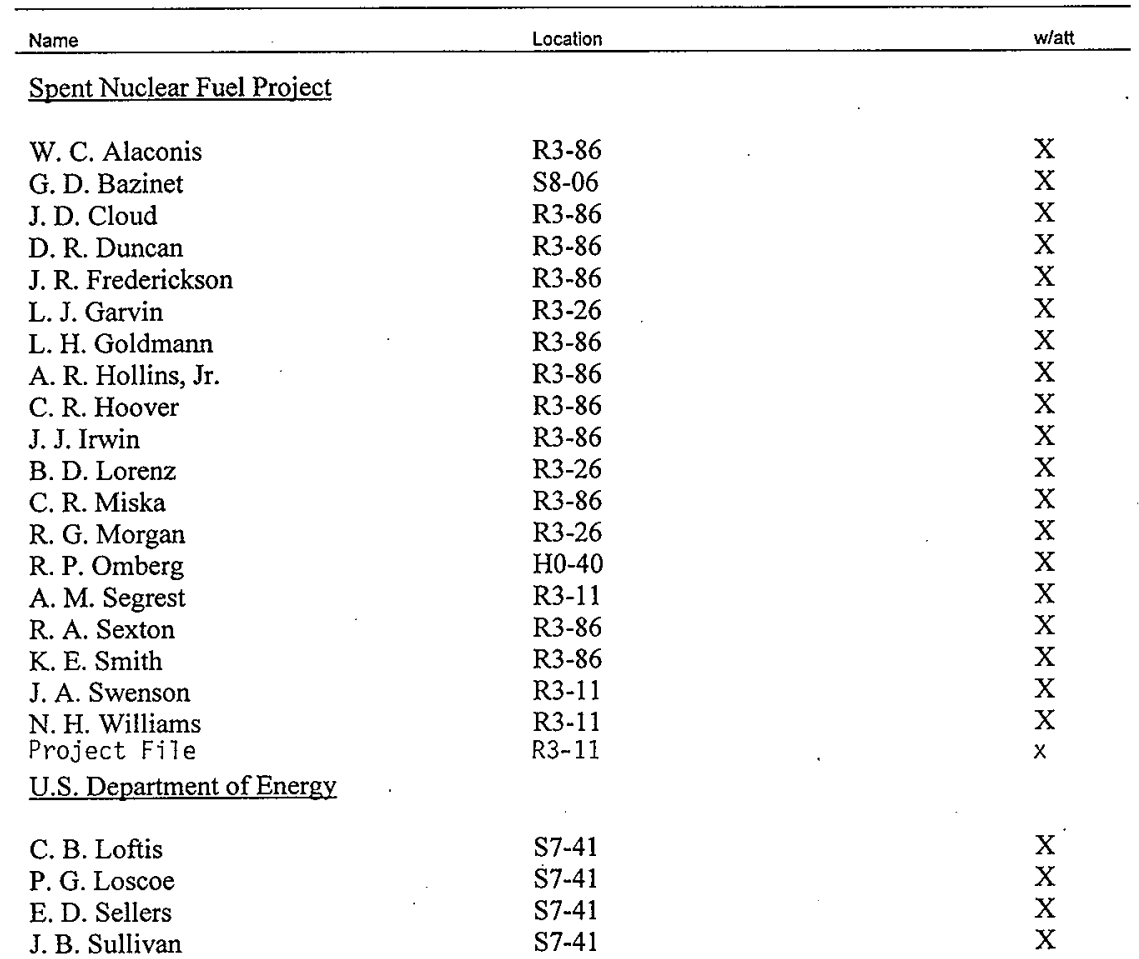




\section{DISTRIBUTION INDEX}

The Multi-Canister Overpack Issue papers listed below are being distributed as a package to facilitate future reference and use by SNF Project personnel. The following issue papers are attached:

1. HNF-2876, Oxygen Gettering Issue Closure Package

2. HNF-3265, MCO Number of Shield Plug Ports

3. HNF-3399, MCO Necessity of the Rupture Disk

4. HNF-3267, MCO Dual Pressure Rating

5. HNNF-3293, MCO Ultrasonic Examination of Closure Weld

6. HNF-3354, MCO Monitoring Issue Closure Package and HNF-3312, MCO Monitoring Activity Description

7. HNF-3292, MCO Sealing Configuration

8. HNF-3266, MCO Design Pressure Rating

9. HNF-3255, ASME Code Requirements for MCO Design and Fabrication

10. HNF-3398, MCO Inservice Inspection and Maintenance

11. HNF-3420, MCO Internal HEPA Filters

12. HNF-3036, Low Reactive Surface Area Issue Closure Package

13. HNF-3270, MCO Pressure Testing 